\title{
Deficit Irrigation Strategies in Vitis vinifera L. cv. Cannonau under Mediterranean Climate. Part II - Cluster Microclimate and Anthocyanin Accumulation Patterns
}

\author{
A. Fernandes de Oliveira* and G. Nieddu \\ Department of Agriculture, University of Sassari, Viale Italia 39, 07100 Sassari, Italy \\ Submitted for publication: October 2012 \\ Accepted for publication: June 2013
}

Key words: Grapevine, water stress, light microclimate, berry temperature, anthocyanin accumulation

\begin{abstract}
The contribution of light and thermal conditions to berry anthocyanin accumulation was investigated in grapevine Vitis vinifera $\mathrm{L}$. cv. Cannonau/1103P subjected to different irrigation strategies in Sardinia, Italy in 2009. In two of the deficit irrigation treatments the root system received $50 \%$ and $25 \%$ crop evapotranspiration (ETc), referred to as DI50 and DI25, respectively. In the third treatment, which included partial root-zone drying (PRD), ETc was set at 50\%. All three treatments were compared to a full irrigation control (FI), thus $\mathbf{1 0 0 \%}$ ETc. Analysis of the thermal conditions during the growing season in 2009 provided evidence for a high frequency of elevated temperatures $\left(>30^{\circ} \mathrm{C}\right)$ during berry development. During ripening, the DI25 clusters intercepted significantly higher intensities $(\mathrm{P}<0.01)$ of solar radiation, UV and PAR, particularly on the southeast canopy side, in comparison to FI and PRD. The analysis of berry temperatures in the DI treatments showed higher exposure to more than $35^{\circ} \mathrm{C}$ in the DI25 southeast berries. Thermal time for anthocyanin accumulation was computed for the DI50 and DI25 berries using normal heat hours (NHH). The patterns of daily NHH showed a reduction in thermal efficiency for anthocyanin accumulation during mid-ripening in the DI25 southeast berries compared to the DI50 ones. The higher temperatures at mid-ripening led to lower total anthocyanin contents in the DI25 berries. However, the coumaroyl-glucoside anthocyanin forms continued to increase in both the DI50 and DI25 berries, while a significant reduction in berry total contents of these forms was observed in FI and PRD. Both deficit irrigation and light conditions in the DI25 berries favoured the accumulation of more colourstable anthocyanins in the berry skin until harvest, namely p-coumaroyl-glucoside and acetyl-glucoside forms.
\end{abstract}

\section{INTRODUCTION}

A number of studies worldwide have demonstrated that grapevine water deficit reduces shoot growth, yield and fruit size, and alters fruit composition (Bravdo et al., 1985; Matthews \& Anderson, 1989; Kennedy et al., 2002; Roby et al., 2004; Castellarin et al., 2007; Bindon et al., 2008), all of which may contribute to altered wine sensory attributes (Matthews et al., 1990; Chapman et al., 2005; Bindon et al., 2007; Deluc et al., 2009). In red grapes, the occurrence of some water deficit during the growing season has been interpreted as beneficial for quality (Williams \& Matthews, 1990; Santos et al., 2007), but grapevine responses depend on the seasonal timing of this stress (Hardie \& Considine, 1976; Van Zyl, 1984; McCarthy, 1997; Roby et al., 2004). It is generally known that moderate water stress imposed during grape development reduces canopy leaf area density and may positively alter cluster microclimate and the synthesis and accumulation of solutes in the berry (Bergqvist et al., 2001; Downey et al., 2006). Inside a dense canopy, the photosynthetic active radiation (PAR) intensity is very low and flux density values of less than $10 \mu \mathrm{mol} \mathrm{m} \mathrm{m}^{-2} \mathrm{~s}^{-1}$ are frequently registered. In such shaded canopies, the near infrared fraction of the spectrum is relatively bigger, which reduces the red/far red ratio (R:FR) and may have a negative effect on the plant's physiological response to light. On the canopy surface, the ratio R:FR is near 1 , both on sunny and overcast days, but inside the canopy the values decrease to between 0.15 and 0.75 and, in deep shadow, can drop to less than 0.1 (Dry, 2000).

Recent studies indicate that water deficit might promote sugar accumulation, either as a result of inhibiting lateral shoot growth, which induces a reallocation of carbohydrates to the fruit, or as a direct effect of ABA-mediated uptake of hexoses (Deluc et al., 2009). In addition, it is generally agreed

*Corresponding author: E-mail: acortez@uniss.it

Aknowledgements: The authors would like to acknowledge the financial contribution of the Convisar - Vino e Sardegna Consortium (project SQFVS APQ P6), the Sella \& Mosca Winery, and the laboratory staff - Filippo Virdis and Giovanni Ligios. 
that some water deficit is beneficial for the development of different groups of phenolic compounds in growing berries (Bindon et al., 2008). This issue is still not fully understood, yet many authors have observed higher polyphenol concentrations under deficit irrigation treatments than in fully irrigated controls (Roby et al., 2004; Santos et al., 2007; Romero et al., 2010). Either a differential growth response of skin and inner mesocarp tissue to water deficits (Roby \& Matthews, 2004), or a direct stimulation of biosynthesis, may cause such a result (Owen et al., 2009; Gambetta et al., 2010). The effects of water deficit on the sugar and phenol contents of grapevine berries are variety dependent (Schultz, 1996; Gaudillère et al., 2002; Castellarin et al., 2007; Deluc et al., 2009) and not always perceptible. In fact, under the influence of other abiotic stresses, such as light and thermal conditions (Haselgrove et al., 2000; Downey et al., 2004, 2006; Tarara et al., 2008), water deficit effects on berry composition might be partially disguised. Several authors have observed that, when compared to shaded clusters, berries ripened in thinner canopies and under low light intensities presented higher sugar, anthocyanin and total phenol contents and lower acidity, malic acid, $\mathrm{pH}$ and berry weight (Dokoozlian \& Kliewer, 1996; Haselgrove et al., 2000; Bergqvist et al., 2001; Santos et al., 2007). Gaudillère et al. (2002) also observed that the light received by the clusters had a positive effect on total polyphenols, although high cluster exposure to radiation (near $80 \%$ of ambient PAR) may not be desirable for anthocyanin production in berries in hot climates. The response of grape anthocyanins to the variation of light exposure has not been shown to be consistent throughout berry development. For instance, Haselgrove et al. (2000) observed a significantly higher concentration of anthocyanins in sun-exposed grapes of cv. Shiraz shortly after véraison, but the difference was not maintained until harvest. It seems that, as light intensity increases, there is a threshold over which the anthocyanin concentration in the berries declines (Mahbrouk \& Sinoquet, 1998). This may be caused by the elevated temperatures at high light intensities, which can limit anthocyanin accumulation for both a decrease in synthesis and an increase in degradation within the biosynthetic pathway (Bergqvist et al., 2001; Spayd et al., 2002, Mori et al., 2007).

In hot and dry environments, irrigation is used as a means to prevent excessive canopy and berry temperatures, to maintain quality in wine production and, in extreme cases, to guarantee plant survival (Santos et al., 2007; Chaves et al., 2010). Indeed, in areas where air temperatures frequently exceed $35^{\circ} \mathrm{C}$ during ripening, anthocyanin accumulation seems to be blocked (Mori et al., 2007). This is partly due to a decrease in the transcription of anthocyanin biosynthetic genes, which potentially can result in decreased production of anthocyanin, but was found to be caused primarily by an increased degradation of anthocyanins under high temperatures. In fact, Mori et al. (2005a) observed that anthocyanin accumulation on cv. Pinot Noir berry skin was reduced under high night temperatures $\left(30^{\circ} \mathrm{C}\right.$, held constant) compared to berries grown under low night temperatures $\left(30^{\circ} \mathrm{C}\right.$ in daytime $/ 15^{\circ} \mathrm{C}$ at night time). Regarding the anthocyanin profile of the berry skin, the same authors observed a lower proportion of low-methylated anthocyanins (delphinidin-3- glucoside, cyanidin-3-glucoside and petunidin-3-glucoside) and suggested that they either degrade more easily under high night temperatures than peonidin-3-glucoside and malvidin3 -glucoside, or that anthocyanin methylation is enhanced under high night temperatures. In that study, lower activities of anthocyanin biosynthetic enzymes, from mid-ripening onwards, were measured under high night temperatures (Mori et al., 2005b).

According to Spayd et al. (2002), excessive absolute berry temperatures, rather than the differences between fruit and ambient temperatures, reduce anthocyanin concentrations in sun-exposed berries. Yet, some degree of heat is needed for synthesis. Spayd et al. (2002) indicated that the critical temperatures for net anthocyanin accumulation in Merlot berry skin may be between 30 and $35^{\circ} \mathrm{C}$.

Other than temperature, direct sunlight exposure, namely UV radiation, might exert a regulatory effect on flavonoid biosynthesis via gene activity alterations or gene damage, depending on the intensity of the intercepted radiation of the different wave length ranges (Schultz, 2000; Spayd et al., 2002; Cohen et al., 2012). Tarara et al. (2008) observed that, together with high temperatures, exposure to direct solar radiation promoted higher dihydroxylation and a smaller proportion of trihydroxylated anthocyanins, as well as less accumulation of the acylated derivatives of all five anthocyanidins in Merlot berry skin. Yet it seems that, above a potentially low threshold of exposure to solar radiation, temperature becomes a stronger environmental determinant of anthocyanin profiles in berry skin (Tarara et al., 2008). Stage III of ripening (one to three weeks after the onset of colouring) is the most sensitive to anthocyanin accumulation in the berry skins (Yamane et al., 2006).

In our study, the effect of different deficit irrigation strategies on vine physiological performance, growth-yield balance and berry composition were investigated in Vitis vinifera L. cv. Cannonau field-grown grapevines in Sardinia, Italy (Fernandes de Oliveira et al., 2013). During ripening, berry microclimate in the fruit zone was monitored in order to investigate the contribution of light and thermal stresses to berry anthocyanin and phenolic accumulation patterns under water deficit conditions

\section{MATERIALS AND METHODS \\ Field conditions and experimental site}

The study was conducted in a commercial vineyard located in the Nurra wine region, near Alghero, North Sardinia, Italy ( $\left.40^{\circ} 38 \mathrm{~N} ; 8^{\circ} 18^{\prime} \mathrm{E}\right)$ in 2009 . Twelve-year-old Vitis vinifera vines cv. Cannonau grafted onto $1103 \mathrm{P}$ rootstock were planted in northeast-southwest oriented rows. Vines were spaced at $2.5 \mathrm{~m}$ between rows and $1.0 \mathrm{~m}$ along the row and trained to an unilateral cordon $1.2 \mathrm{~m}$ in height, head trained and mechanically hedge-spur pruned.

Irrigation was scheduled according to the water balance method following the methodology proposed by Allen et al. (1998). Full irrigation (FI), deficit irrigation (DI) and partial root-zone drying (PRD) strategies were set, based on weekly estimations of crop evapotranspiration (ETc). Four treatments were imposed: FI, DI50 and DI25 (supplying 100\%, 50\% and $25 \%$ of ETc respectively, simultaneously to both sides of the root system) and PRD (supplying 50\% of ETc to one 
side of the root system, allowing the other side to dry, and alternating the watered side every 15 days). Irrigation was applied using a subsurface drip system, with two lines per row spaced $40 \mathrm{~cm}$ from the plant row and placed at a depth of $40 \mathrm{~cm}$. On each line, drippers were spaced $50 \mathrm{~cm}$ apart and the discharge rate for each emitter was $2 \mathrm{~L} \mathrm{~h}^{-1}$. The experimental design consisted of three randomised blocks with three contiguous rows per treatment. The experimental plots consisted of 10 plants per replicate, with an interval of 20 plants between replicates. In each replicate, data were collected on the central row, while the adjacent ones were considered buffer rows.

\section{Weather data}

Monthly weather conditions from April to September 2009 and the 30-year (1971 to 2000) monthly average data from the closest weather station (Alghero Fertilia, $40^{\circ} 37^{\prime} 52^{\prime \prime}$ $\mathrm{N} ; 8^{\circ} 17$ ' 19" E), gathered by the "Aeronautica Militare" (2009), were analysed. Maximum, mean and minimum monthly temperatures, as well as the number of days with temperatures higher than $25^{\circ} \mathrm{C}$ and $30^{\circ} \mathrm{C}$, were reported (Table 1) and discussed.

\section{Irrigation scheduling}

The meteorological data from the weather station of Alghero Fertilia were also used to compute the reference evapotranspiration (ETo). The different phenological stages were taken into account for estimating ETc. A crop coefficient of 0.8 was set up for each treatment (Williams \& Ayars, 2005). The water supply was then calculated considering the effective rainfall of each given period and soil available water (SAW) of $55 \%$. Finally, to determine the watering volume, a $10 \%$ loss of efficiency of the irrigation system was used (Brouwer et al., 1989). Irrigation started after fruit set (mid-June) and ended three weeks before harvest (on 20 August) (Fernandes de Oliveira et al., 2013).

\section{Light microclimate in the fruit zone}

Light interception and its spectral composition were monitored using a pyranometer for global irradiance $(\mathrm{Rg})$, and single sensors for photosynthetic active radiation (PAR; from 400 to $700 \mathrm{~nm}$ ), red:far red (R:FR; 660:730 nm), ultraviolet-A (UV-A; 320-400 nm) and ultraviolet-B (UVB; 280-320 nm), all coupled to a portable datalogger (Skye Instruments Ltd., UK). The measurements took place in the fruit zone at two different grape positions: the sides of the row facing northwest (NW) and southeast (SE). Data are reported as average values of nine replicates per treatment and are expressed in $\mu \mathrm{mol} \mathrm{m} \mathrm{m}^{-2} \mathrm{~s}^{-1}$ for PAR, in $\mathrm{W} \mathrm{m} \mathrm{m}^{-2}$ for $\mathrm{Rg}$ and UV-A, and in $\mathrm{mW} \mathrm{m}^{-2}$ for UV-B data. Light microclimate measurements were taken simultaneously at solar noon, under clear sky conditions.

\section{Berry thermal microclimate}

During ripening (from 2009-08-24 until 2009-09-13), berry temperatures were monitored in the DI50 and DI25 treatments on a daily basis by inserting microprobes of copper-constantan fine wire (thermistors GMR Strumenti, IT) into the berries. Three clusters with different exposures (internal, and the sides of the vine row facing northwest and southeast) were selected for the monitoring of berry temperature $\left(\mathrm{T}_{\mathrm{b}}\right)$. An additional sensor was placed inside the canopy to allow simultaneous registration of canopy temperature. The thermistors were connected to fourchannel dataloggers (Zeta-tec Co., UK) for the continuous registration of temperature (frequency of 10 minutes).

\section{Thermal time for anthocyanin accumulation}

To evaluate the temperature effect on the efficiency of anthocyanin synthesis, thermal time was computed by transforming hourly average berry temperatures into normal heat hours (NHH) using a physiological model (Cola et al., 2012). This model uses beta distribution as a temperature response curve for phenological processes (Yan \& Hunt, 1999) and quantifies the hours spent at a certain temperature, attributing them a value between 0 and 1 ( 0 when temperatures are inferior to the minimum cardinal temperature or higher than the maximum cardinal temperature, and 1 when the temperature corresponds to the optimum cardinal temperature). In order to quantify the thermal requirements for anthocyanin synthesis and accumulation, a minimum of $10^{\circ} \mathrm{C}$, a maximum of $35^{\circ} \mathrm{C}$, and an optimum of $26^{\circ} \mathrm{C}$ were used in the model as cardinal temperatures for PAL (phenylalanine ammonia-lyase) activity. PAL is a key enzyme of the anthocyanin biosynthesis pathway (Rustioni et al., 2006).

\section{Berry composition}

From véraison until harvest, representative cluster fractions with different positions within the canopy were sampled

TABLE 1

Monthly thermal conditions observed during the 2009 growth season and long-term monthly 30-year average (1971 to 2000 ) in Alghero, Sardinia, Italy (Aeronautica Militare, 2009).

\begin{tabular}{ccccccccccc}
\hline & \multicolumn{2}{c}{$\operatorname{Max~T}\left({ }^{\circ} \mathrm{C}\right)$} & \multicolumn{2}{c}{ Mean T $\left({ }^{\circ} \mathrm{C}\right)$} & \multicolumn{2}{c}{ Min T $\left({ }^{\circ} \mathrm{C}\right)$} & \multicolumn{2}{c}{ Days T $>25^{\circ} \mathrm{C}$} & \multicolumn{2}{c}{ Days $\mathrm{T}>30^{\circ} \mathrm{C}$} \\
\hline & 2009 & 30 -year & 2009 & 30 -year & 2009 & 30 -year & 2009 & 30 -year & 2009 & 30 -year \\
\hline Apr & 18.9 & 17.6 & 14.2 & 13.0 & 9.1 & 8.3 & 1 & 0.5 & 0 & 0.0 \\
May & 27.0 & 22.0 & 19.6 & 16.7 & 11.8 & 11.5 & 22 & 6.9 & 7 & 0.0 \\
Jun & 28.3 & 26.0 & 22.3 & 20.5 & 15.8 & 15.0 & 27 & 16.9 & 7 & 4.9 \\
Jul & 32.1 & 29.4 & 25.3 & 23.4 & 18.1 & 17.4 & 30 & 27.7 & 24 & 13.8 \\
Aug & 33.0 & 29.8 & 25.9 & 23.9 & 18.5 & 18.0 & 31 & 29.8 & 27 & 15.5 \\
Sep & 28.1 & 26.6 & 22.1 & 21.2 & 16.2 & 15.8 & 28 & 21.2 & 7 & 4.5 \\
\hline
\end{tabular}

Max $\mathrm{T}=$ maximum temperature; mean $\mathrm{T}=$ mean temperature; $\min \mathrm{T}=$ minimum temperature 
every two weeks to monitor ripening. Berry weight, total soluble solids ( ${ }^{\circ}$ Brix), $\mathrm{pH}$, titratable acidity (g tartaric acid $\left.\mathrm{L}^{-1}\right)$, total anthocyanin content (mg malvin $100 \mathrm{~g}^{-1}$ ) and total phenol content (mg catechin $\mathrm{L}^{-1}$ ) were analysed (OIV, 1990). The anthocyanin profile was evaluated using the method proposed by Di Stefano \& Cravero (1991).

\section{Statistical analysis}

Statistical data analysis was performed using SPSS software version 16 for the analysis of variance (ANOVA) and the least significant difference (LSD) test for mean separation. Significant differences are represented in the tables by letters, and in the figures the symbols $*, * *, * * *$ and ns represent significant differences for $\mathrm{P}$ values $<0.05,0.01$, 0.001 and non-significant difference respectively. Sunlight cluster microclimate data (for Rg, PAR, UV-A, UV-B and $\mathrm{R}: \mathrm{FR}$ ) were subjected to two-way (irrigation $\mathrm{x}$ canopy side) ANOVA, using the general linear model procedure for splitplot design to separate the effects of irrigation strategy and canopy side, and to observe interactive effects.

\section{RESULTS AND DISCUSSION \\ Season thermal conditions}

In the Nurra region, the 2009 growing season was characterised by hot weather conditions in comparison to the average 30-year data (Aeronautica Militare, 2009). During April, both the maximum, mean and minimum temperatures, as well as the number of days with temperatures higher than $25^{\circ} \mathrm{C}$, remained close to the average values of the 30 year series (Table 1). During the months of May, July and August 2009, elevated maximum and mean temperatures were registered; also, a higher frequency of number of days with elevated temperatures (higher than $25^{\circ} \mathrm{C}$ and $30^{\circ} \mathrm{C}$ ) was reached compared to the 30 -year average values. In May, maximum and mean temperatures were $5^{\circ} \mathrm{C}$ and $2.9^{\circ} \mathrm{C}$ higher than the 30-year average respectively, and the days with temperatures higher than $25^{\circ} \mathrm{C}$ were 15.5 more than the 30-year average. During July and August, maximum temperatures were 2.7 and $3.2^{\circ} \mathrm{C}$ higher than the 30 -year values respectively, while mean temperatures were nearly $2{ }^{\circ} \mathrm{C}$ higher than the 30 -year average. Compared to the 30 year average, July and August had about +10.2 and +11.5 days of $\mathrm{T}>30^{\circ} \mathrm{C}$ respectively (Table 1 ). The maximum and minimum temperatures in September remained close to the 30 -year average values (about $+1.5^{\circ} \mathrm{C}$ ), and the number of days with temperatures higher than $30^{\circ} \mathrm{C}$ was only 2.5 . A $50 \%$ increase in the frequency of days with elevated temperatures has been registered since 2000, and the number of hot days recorded reached a maximum during 2009 (ARPAS, 2010). The thermal surplus recorded in the period from May to August, and the maximum extremes, particularly in July, resulted in an acceleration of the developmental phenology, with technological maturity (of sugars, titratable acidity and $\mathrm{pH}$ ) being brought forward by five to 10 days (ARPAS, 2010).

\section{Light microclimate in the fruit zone}

Significant differences were observed in the quantity of sunlight intercepted in the fruit zone during the ripening period (Table 2). Regarding the effect of the canopy side, the clusters facing southeast were exposed to higher $\mathrm{Rg}$ intensity in all the deficit irrigation treatments (nearly 250 $\mathrm{W} \mathrm{m} \mathrm{m}^{-2}$ against the nearly $80 \mathrm{~W} \mathrm{~m}^{-2}$ of the northwest-facing clusters on 31 July), but not in the fully irrigated plants at véraison. The differences between irrigation treatments were not statistically significant before ripening. This result is in accordance with the reported total leaf area values observed in July, which were similar in all the irrigation treatments (Fernandes de Oliveira et al., 2013). Conversely, on 200909-21, the differences between treatments in terms of leaf area formation and abscission led to a highly significant different light interception in the fruit zone, both due to irrigation strategy and canopy side effects. As the main leaves started to senesce close to harvest, the DI25 clusters became more exposed to solar radiation, thus displaying higher PAR interception than in July and a significantly different light microclimate, with statistically higher $\mathrm{Rg}$ and UV radiation interception and R:FR ratio on both sides of the canopy compared to the PRD treatment (Table 2). Furthermore, in the clusters on the SE side, significantly higher light intensities were measured in PAR wavelengths in DI25. During ripening, the differences between clusters on the NW and SE sides became highly significant, and the increases in leaf area of the FI and PRD treatments throughout the ripening period resulted in lower solar radiation transmission into the fruit zone, namely in the PAR wavelength, compared to that on the previous dates.

As far as the R:FR ratio was concerned, low values were recorded in the cluster zone on both sides of the canopy in every irrigation treatment on the first measuring date (below 0.30) in comparison to the second one, with no significant differences being detected between either irrigation treatments or canopy sides. By the time the second measurement was taken, however, the R:FR ratio had already increased significantly in the FI, DI50 and DI25 plants (above 0.48) and expressly in the SE side of the DI25 plants (to 0.72), which had already lost a significant part of their main and lateral leaf area. Conversely, the lowest sunlight intensities and R:FR ratios in the fruit zone were recorded in PRD plants, on both the SE and NW sides of the canopy. This result demonstrates that the increase in leaf area in the PRD plants during ripening led to a significantly shadier light microclimate in the cluster zone.

\section{Berry thermal microclimate Average daily berry temperature}

Fig. 1 shows the average daily berry temperatures $\left(\mathrm{T}_{\mathrm{b}}\right)$ on the SE and NW canopy sides of the DI50 and DI25 plants over seven days in the mid-ripening period (2009-09-01 to 2009-09-07). This was the period in which $T_{b}$ differed the most between treatments and canopy sides. On average, the variation in $\mathrm{T}_{\mathrm{b}}$ was less than $1^{\circ} \mathrm{C}$ between the DI50 and DI25 berries on the NW side, while on the SE side of the canopy, DI25 reached as much as $+4.6{ }^{\circ} \mathrm{C}$ in relation to the DI50 SE berries. Furthermore, the DI25 SE berries reached more than $35^{\circ} \mathrm{C}$ on six of the abovementioned seven days, while the DI50 SE berries remained below the $35^{\circ} \mathrm{C}$ threshold, reaching a maximum value of about $33.8^{\circ} \mathrm{C}$ on 2009-0902. The lowest $T_{b}$ values were obtained on the SE side of the DI50 berries from 2009-09-05 to 2009-09-07, when it 
TABLE 2

Canopy light microclimate in the fruit zone at pre-véraison (2009-07-31) and prior to harvest (2009-09-21).

\begin{tabular}{|c|c|c|c|c|c|c|}
\hline & $\begin{array}{c}\text { Treatment/ } \\
\text { canopy side }\end{array}$ & $\begin{array}{c}\mathrm{Rg} \\
\left(\mathrm{W} / \mathrm{m}^{2}\right)\end{array}$ & $\mathrm{UV}-\mathrm{A}\left(\mathrm{W} / \mathrm{m}^{2}\right)$ & $\begin{array}{c}\mathrm{UV}-\mathrm{B} \\
\left(\mathrm{mW} / \mathrm{m}^{2}\right)\end{array}$ & 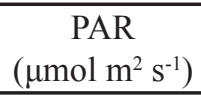 & $\mathrm{R}: \mathrm{FR}$ \\
\hline \multicolumn{7}{|c|}{ Pre-véraison } \\
\hline \multirow[t]{2}{*}{ FI } & $\mathrm{NE}$ & 156 & 2.70 & 176 & 139 & 0.26 \\
\hline & NW & 82 & 1.42 & 77 & 47 & 0.19 \\
\hline \multirow[t]{2}{*}{ DI50 } & $\mathrm{NE}$ & 257 & 3.28 & 115 & 239 & 0.26 \\
\hline & NW & 82 & 1.21 & 110 & 35 & 0.18 \\
\hline \multirow[t]{2}{*}{ PRD } & $\mathrm{NE}$ & 260 & 2.37 & 146 & 167 & 0.27 \\
\hline & NW & 78 & 3.42 & 174 & 68 & 0.29 \\
\hline \multirow[t]{2}{*}{ DI25 } & $\mathrm{NE}$ & 237 & 2.40 & 71 & 278 & 0.27 \\
\hline & NW & 78 & 1.84 & 87 & 43 & 0.26 \\
\hline \multicolumn{7}{|c|}{ Effects } \\
\hline \multirow{3}{*}{ Sig. } & Irrigation & ns & ns & ns & ns & ns \\
\hline & Side & $\begin{array}{c}* \\
\mathrm{NE}>\mathrm{NW}\end{array}$ & ns & ns & $\begin{array}{c}* \\
\mathrm{NE}>\mathrm{NW}\end{array}$ & ns \\
\hline & Irrig x Side & ns & ns & ns & ns & ns \\
\hline \multicolumn{7}{|c|}{ Pre-harvest } \\
\hline \multirow[t]{2}{*}{ FI } & $\mathrm{NE}$ & 139 & 2.92 & 71 & 151 & 0.69 \\
\hline & NW & 61 & 1.52 & 51 & 55 & 0.50 \\
\hline \multirow[t]{2}{*}{ DI50 } & $\mathrm{NE}$ & 149 & 2.52 & 70 & 186 & 0.55 \\
\hline & NW & 72 & 2.00 & 89 & 68 & 0.48 \\
\hline \multirow[t]{2}{*}{ PRD } & $\mathrm{NE}$ & 128 & 1.50 & 49 & 115 & 0.29 \\
\hline & NW & 61 & 1.48 & 55 & 43 & 0.34 \\
\hline \multirow[t]{2}{*}{ DI25 } & $\mathrm{NE}$ & 319 & 4.00 & 251 & 303 & 0.72 \\
\hline & NW & 82 & 2.75 & 96 & 75 & 0.58 \\
\hline \multicolumn{7}{|c|}{ Effects } \\
\hline & Irrigation & $* * *$ & $*$ & $*$ & $*$ & $* *$ \\
\hline \multirow{4}{*}{ Sig. } & & $\begin{array}{c}\mathrm{FI}=\mathrm{DI} 50=\mathrm{PRD}< \\
\mathrm{DI} 25\end{array}$ & $\mathrm{PRD}<\mathrm{DI} 25$ & $\begin{array}{c}\mathrm{FI}=\mathrm{DI} 50=\mathrm{PRD}< \\
\mathrm{DI} 25\end{array}$ & $\mathrm{PRD}<\mathrm{DI} 25$ & $\begin{array}{c}\mathrm{FI}=\mathrm{DI} 50=\mathrm{PRD}< \\
\mathrm{DI} 25\end{array}$ \\
\hline & Side & $* * *$ & ns & ns & $* * *$ & ns \\
\hline & & $\mathrm{NE}>\mathrm{NW}$ & & & $\mathrm{NE}>\mathrm{NW}$ & \\
\hline & Irrig x Side & $* * *$ & ns & ns & ns & ns \\
\hline
\end{tabular}

Mean values $(\mathrm{n}=9)$ and two-way ANOVA; $\mathrm{ns}, * * *$ and $* * *$ represent not significant, and significant differences at $\mathrm{P}<0.05$, 0.01 and 0.005 respectively.

Global solar radiation (Rg), Ultraviolet-A and B (UV-A and UV-B), PAR interception and red/far red ratio (R:FR).

reached about $13^{\circ} \mathrm{C}$ during the night. Meanwhile, on those three nights, the minimum $\mathrm{T}_{\mathrm{b}}$ in the DI25 southeast berries reached as much as $20.7^{\circ} \mathrm{C}, 18.9^{\circ} \mathrm{C}$ and $17.4^{\circ} \mathrm{C}$. On the NW side of the canopy, average $\mathrm{T}_{\mathrm{b}}$ was not significantly different between the two DI treatments. On this canopy side, the maximum $\mathrm{T}_{\mathrm{b}}$ reached more than $35^{\circ} \mathrm{C}$ on five of the seven days, and during the night the temperature remained above $20^{\circ} \mathrm{C}$ in DI50, while it reached lower values in the DI25 berries (nearly $18^{\circ} \mathrm{C}$ ) on 2009-09-06 and 2009-09-07.

\section{Permanence of elevated temperatures}

Additional information on the occurrence of elevated temperatures during ripening was obtained by computing the permanence of defined ranges of $\mathrm{T}_{\mathrm{b}}\left(<10^{\circ} \mathrm{C}, 10^{\circ} \mathrm{C}<\mathrm{T}_{\mathrm{b}}<\right.$ $35^{\circ} \mathrm{C}$, and $>35^{\circ} \mathrm{C}$ ). Fig. 2 reports the percentage of time during which the DI50 and DI25 berries located on the SE and
NW sides of the canopy were exposed to the defined ranges of temperature during ripening. In every cluster location, temperatures below the low threshold for grapevine growth $\left(10^{\circ} \mathrm{C}\right)$ were not recorded on any canopy side of the two DI treatments. The DI25 SE berries were exposed to more than $35^{\circ} \mathrm{C}$ for nearly $30 \%$ of the time, while the permanence of such elevated temperatures was only $6.3 \%$ of the ripening period on the SE side of the DI50 berries. Berries on the NW side of DI50 and DI25 were exposed to T $>35^{\circ} \mathrm{C}$ for $15 \%$ and $10 \%$ of the time respectively. The permanence of high temperatures during the hot season of 2009 led to an overall low total anthocyanin content at harvest in both DI treatments (Table 3), but much more markedly in DI25, in which berries on the SE side were exposed to elevated temperatures for twice the length of time as those on the NW side of DI50 and as much as five times more than DI50 SE berries. 

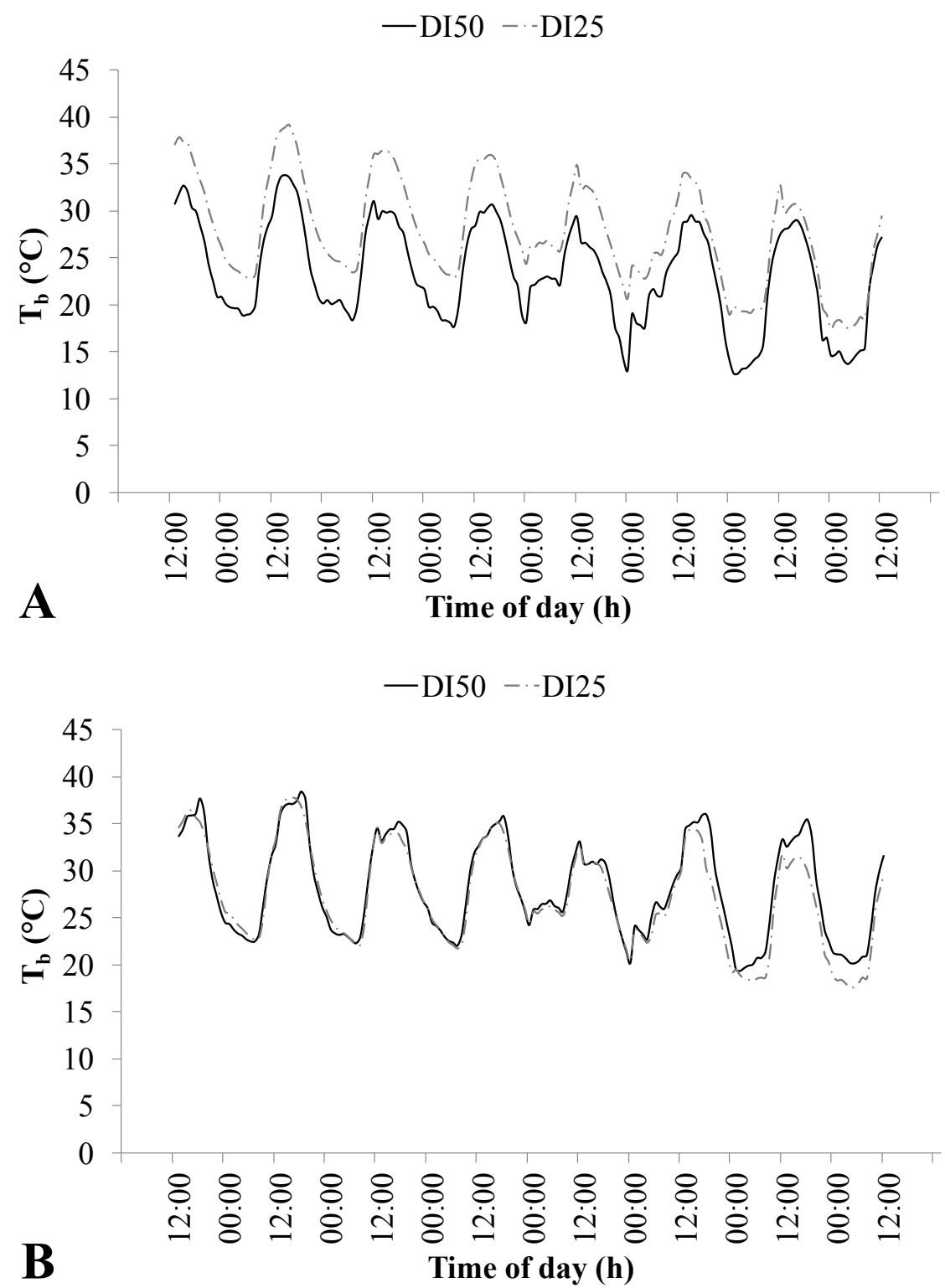

FIGURE 1

Diurnal variation in berry temperature $\left(\mathrm{T}_{b},{ }^{\circ} \mathrm{C}\right)$ over seven days of the mid-ripening period (from 2009-09-01 to 2009-09-07) in the DI50 and DI25 treatments. Mean $T_{b}$ values $(n=4)$ on southeast $(A)$ and northwest $(B)$ sides of the canopy.

\section{Seasonal berry temperature patterns}

In order to better characterise thermal conditions in the clusters of the two DI treatments, the average patterns of maximum, mean and minimum daily berry temperature, during the entire ripening period, were evaluated and are reported in Fig. 3 (A and B). The shaded vertical bars on each graph indicate the mid-ripening period. $T_{b}$ was very high at the beginning of ripening, but decreased progressively during the first week of monitoring. On the SE side, similar maximum, mean and minimum $\mathrm{T}_{\mathrm{b}}$ values were recorded in DI50 and DI25, both at the beginning of ripening and in the week prior to harvest. However, from mid-ripening until harvest, maximum and mean $\mathrm{T}_{\mathrm{b}}$ reached significantly higher values in SE DI25 berries, averaging nearly $5^{\circ} \mathrm{C}$ higher than DI50. At mid-ripening, the minimum $\mathrm{T}_{\mathrm{b}}$ also remained significantly higher in the DI25 SE berries (about $28^{\circ} \mathrm{C}$ against the $18^{\circ} \mathrm{C}$ of the DI50 SE berries), but in the week prior to harvest $\mathrm{T}_{\mathrm{b}}$ decreased to nearly $12^{\circ} \mathrm{C}$ in both DI treatments. Regarding the NW side of the canopy, the DI50 berries reached elevated daily $T_{b}$, but at mid-ripening the differences between the DI50 and DI25 NW berries were not statistically significant. The higher maximum $\mathrm{T}_{\mathrm{b}}$ values reached in the berries on the SE side of the DI25 plants during ripening are in accordance with the significantly higher sunlight exposure reported before (Table 2), and were due to a higher cluster exposure as leaf abscission had begun in DI25. For the same reason, in the last week before harvest, after the first September rain events, the temperature decreased more rapidly in the more exposed DI25 berries than in the DI50 berries.

\section{Physiologic efficiency of anthocyanin synthesis}

DI50 and DI25 presented similar berry composition (Fernandes de Oliveira et al., 2013), but on the last two sampling dates the total anthocyanin content was significantly higher in DI50 than in FI and DI25 (Table 3). Meanwhile, the total amounts in the DI50 and PRD berries did not differ significantly. When berry temperatures were normalised into NHH according to their physiological efficiency for 


$$
\square \mathrm{Tb}>35^{\circ} \mathrm{C} \quad \square 10<\mathrm{Tb}<35^{\circ} \mathrm{C} \quad \square \mathrm{Tb}<10^{\circ} \mathrm{C}
$$

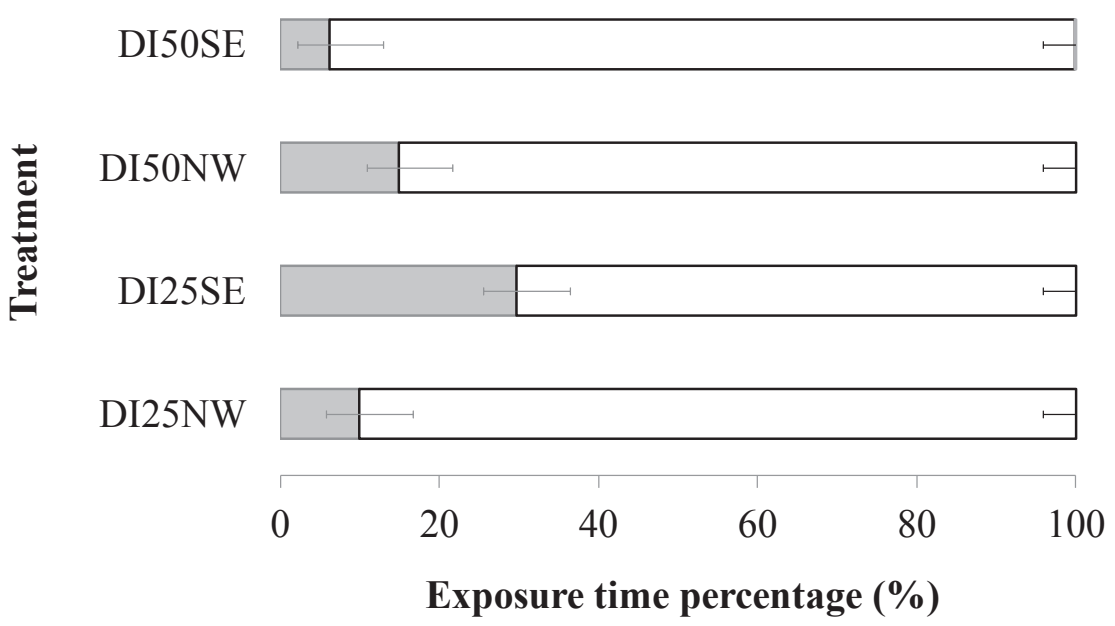

FIGURE 2

Berry percentage of exposure time to temperature $\left(\mathrm{T}_{\mathrm{b}}\right)$ ranges $\left(<10^{\circ} \mathrm{C} ; 10^{\circ} \mathrm{C}<\mathrm{T}_{\mathrm{b}}<35^{\circ} \mathrm{C} ;>35^{\circ} \mathrm{C}\right)$ during ripening in the southeast (SE) and northwest (NW) side berries of DI50 and DI25. Mean values $(n=4) \pm \mathrm{SE}$
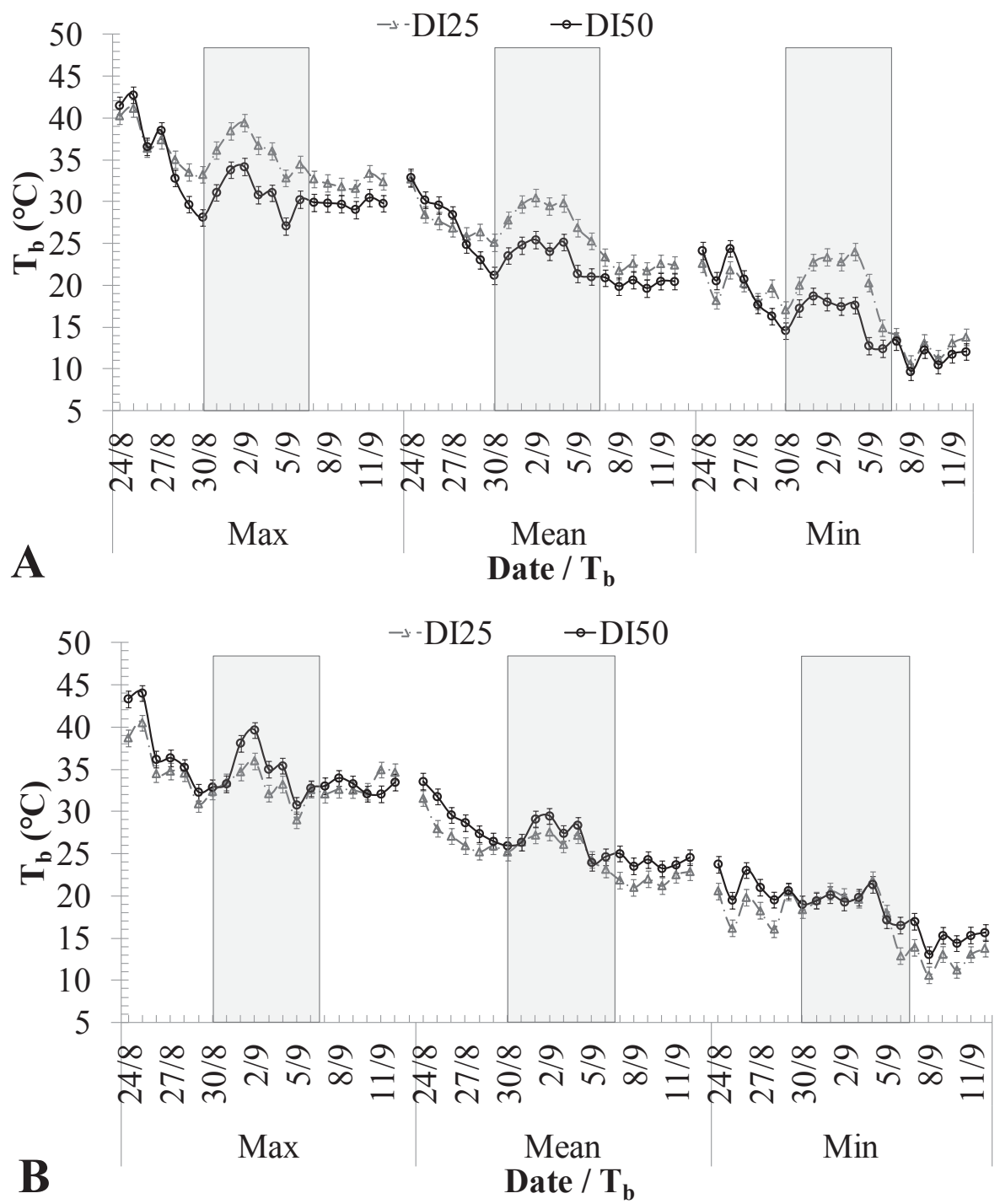

FIGURE 3

Seasonal trends of daily maximum, mean and minimum berry temperature $\left(\mathrm{T}_{\mathrm{b}}\right)$ in the DI50 and DI25 treatments on the southeast (A) and northwest (B) sides of the canopy during ripening in 2009. Mean values $(n=4) \pm S E$ 
anthocyanin synthesis, important fluctuations were observed during the season for both DI treatments (Fig. 4). Despite the higher daily NHH computed in DI25 at the beginning of ripening and prior to harvest, the high temperatures recorded during mid-ripening in the DI25 SE berries led to a decrease in daily $\mathrm{NHH}$ at this stage. Furthermore, the total anthocyanin content of the DI25 berries became significantly lower than that in DI50 after mid-ripening, as stated before. Hence, it is reasonable to consider that the higher temperatures recorded during mid-ripening greatly affected anthocyanin synthesis in the DI25 berries, and that, after the partial degradation of the previously accumulated anthocyanins, the synthesis did not recover substantially. In fact, after mid-ripening the total anthocyanin content became significantly lower in the DI25 compared to the DI50 berries, and the total content continued to decrease until harvest.

\section{Anthocyanin accumulation pattern}

The lower total anthocyanin content of the DI25 berries was likely a consequence of the high exposure to elevated temperatures, namely on the SE side of the canopy (Table 3 and Figs 3 and 4), rather than a direct effect of the imposed water deficit. These results are in accordance with those obtained by Mori et al. (2005a, 2005b, 2007) and Yamane et al. (2006). In fact, from mid-ripening onwards, significantly higher sunlight exposure was recorded in the fruit zone of the DI25 plants and, under the significantly higher temperatures of this period, partial degradation of the accumulated anthocyanin was observed, primarily of the monoglucoside forms (Fig. 5). Despite the significantly higher content of monoglucosides (namely malvidin) measured in the DI25 berries two weeks after véraison, a significant reduction in these anthocyanin forms occurred from mid-ripening onwards (Fig. 5). On the other hand, the higher proportion of the more complex but normally less abundant acylated forms (Rodriguez-Sanoa et al., 1999) found in DI25 compared to FI and DI50 could be ascribed to a beneficial effect of water deficit on the berry anthocyanin profile. Furthermore, until four weeks before harvest, a PRD effect on the anthocyanin profile in the berry
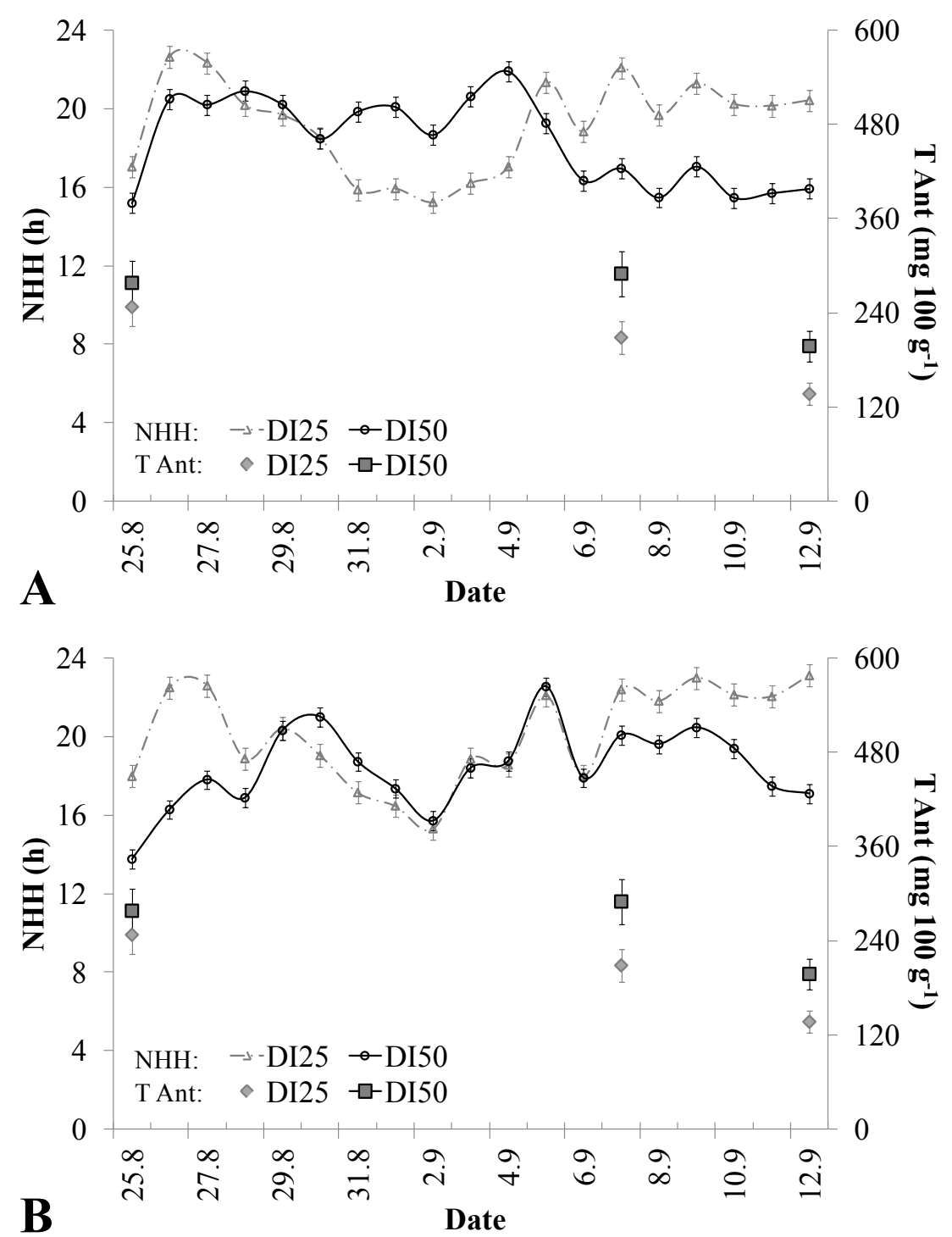

FIGURE 4

Seasonal trends in daily normal heat hours (NHH) on the southeast (A) and northwest (B) sides of the canopy during ripening in 2009 (from 24 August until 13 September) and berry total anthocyanin content (T Ant) in the DI50 and DI25 treatments.

Mean values $(n=4) \pm S E$ 
TABLE 3

Effect of irrigation treatments on berry fresh (BFW) and dry (BDW) weight and total anthocyanin content (T Ant) during ripening and at harvest.

\begin{tabular}{|c|c|c|c|c|}
\hline Date & Treatment & $\begin{array}{l}\text { BFW } \\
(\mathrm{g})\end{array}$ & $\begin{array}{l}\text { BDW } \\
(\mathrm{g})\end{array}$ & $\begin{array}{c}\text { T Ant } \\
\left(\mathrm{mg} 100 \mathrm{~g}^{-1}\right)\end{array}$ \\
\hline \multirow{5}{*}{ 28.07.2009 } & FI & $1.52^{\mathrm{a}}$ & 0.19 & 50.7 \\
\hline & DI50 & $1.34^{\mathrm{ab}}$ & 0.18 & 63.2 \\
\hline & PRD & $1.12^{\mathrm{b}}$ & 0.15 & 64.8 \\
\hline & DI25 & $1.29^{\mathrm{ab}}$ & 0.18 & 42.7 \\
\hline & Sig. & $*$ & ns & ns \\
\hline \multirow{5}{*}{10.08 .2009} & FI & 1.88 & 0.37 & 170.3 \\
\hline & DI50 & 1.77 & 0.35 & 162.1 \\
\hline & PRD & 1.68 & 0.34 & 163.7 \\
\hline & DI25 & 1.88 & 0.36 & 160.6 \\
\hline & Sig. & ns & $\mathrm{ns}$ & $\mathrm{ns}$ \\
\hline \multirow{5}{*}{ 24.08.2009 } & FI & 1.85 & 0.44 & 202.8 \\
\hline & DI50 & 1.97 & 0.45 & 278.1 \\
\hline & PRD & 1.95 & 0.41 & 198.0 \\
\hline & DI25 & 2.03 & 0.44 & 247.5 \\
\hline & Sig. & ns & ns & ns \\
\hline \multirow{3}{*}{ 07.09.2009 } & FI & $2.10^{\mathrm{ab}}$ & 0.50 & $165.0^{\mathrm{b}}$ \\
\hline & DI50 & $2.25^{\mathrm{a}}$ & 0.57 & $289.9^{\mathrm{a}}$ \\
\hline & PRD & $2.06^{b}$ & 0.52 & $225.7^{\mathrm{ab}}$ \\
\hline \multirow{7}{*}{ 22.09.2009 } & DI25 & $2.25^{\mathrm{a}}$ & 0.54 & $208.6^{\mathrm{b}}$ \\
\hline & Sig. & $*$ & ns & $*$ \\
\hline & FI & $2.57^{\mathrm{a}}$ & $0.57^{\mathrm{a}}$ & $112.3^{\mathrm{b}}$ \\
\hline & DI50 & $2.47^{\mathrm{a}}$ & $0.59^{\mathrm{a}}$ & $197.7^{\mathrm{a}}$ \\
\hline & PRD & $2.10^{b}$ & $0.52^{\mathrm{b}}$ & $139.9^{\mathrm{ab}}$ \\
\hline & DI25 & $2.27^{b}$ & $0.53^{\mathrm{b}}$ & $136.8^{\mathrm{b}}$ \\
\hline & Sig. & $*$ & $*$ & $*$ \\
\hline
\end{tabular}

Mean values $(\mathrm{n}=9)$ and ANOVA for $\mathrm{P}<0.05 ; \mathrm{ns}=$ not significant

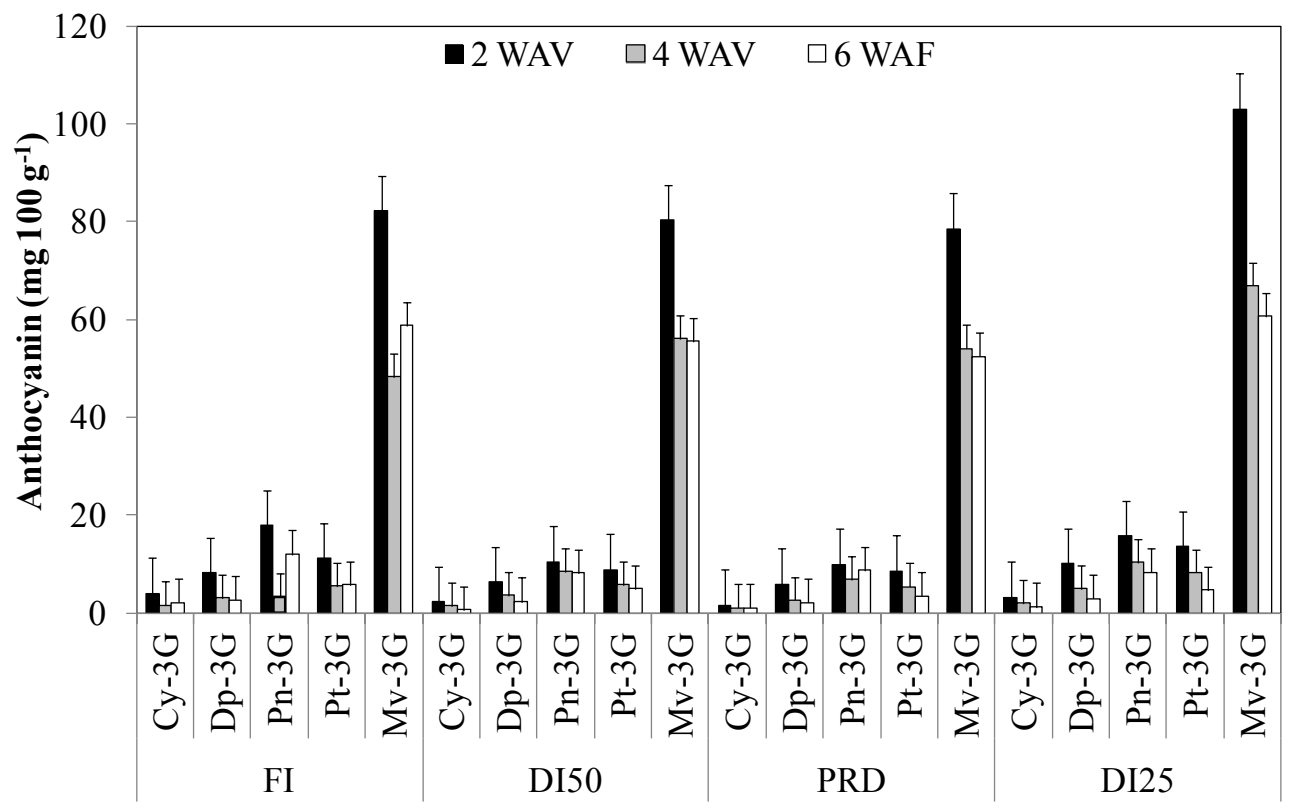

FIGURE 5

Changes in monoglucoside anthocyanin accumulation in the skin of berries grown under the FI, DI50, PRD and DI25 treatments. Mean values $\pm \mathrm{SE}(\mathrm{n}=9)$. WAV = weeks after véraison; $\mathrm{Cy}=$ cyanidin; $\mathrm{Dp}=$ delphinidin; $\mathrm{Pn}=$ peonidin; $\mathrm{Pt}=\mathrm{petunidin} ; \mathrm{Mv}$ $=$ malvidin $3 \mathrm{G}=3$-glucoside 
skin (Bindon et al., 2008) was also observed: compared to the DI50 treatment irrigated with the same amount, PRD induced a greater proportion of acylated forms than malvidin-glucosides. Among the p-coumaroyl-glucoside forms, a higher proportion of trihydroxylated anthocyanins (delphinidin, petunidin and mostly malvidin) was measured in DI25 and, among the acetyl-glucosides, delphinidin and petunidin derivatives were also significantly higher (Fig. 6A and B). In fact, the opposite effect would be expected as a consequence of higher sunlight and temperature exposure: a decreased proportion of trihydroxylated anthocyanins, increased dihydroxylated ones and less acylated derivatives (Tarara et al., 2008). Yet despite the elevated $\mathrm{T}_{\mathrm{b}}$ recorded in DI25, the more stable anthocyanin forms continued to increase in both the DI50 and DI25 berries, while a significant reduction in the total content of these forms was observed in FI and PRD. In addition, the two DI treatments did not differ significantly in both berry fresh and dry weight until one week before harvest. However, at harvest, the DI25 and PRD berries had a significantly lower berry weight compared to the FI and DI50 berries. The absence of differences in berry fresh and dry weight rules out the occurrence of differential berry skin/pulp growth in the PRD and DI25 treatments. In the PRD plants, the higher total leaf area, which led to a shadier light microclimate, might ultimately have caused a differential anthocyanin metabolism compared to the DI treatments.

The increased exposure to high temperatures in the DI25 berries reduced the differences in berry skin anthocyanin profiling between treatments at harvest. Higher anthocyanin degradation occurred in the DI25 berries in the last weeks of ripening, and in particular affected berry skin monoglucosides and the acetil-glucoside forms (Fig. 5 and Fig. 6A).
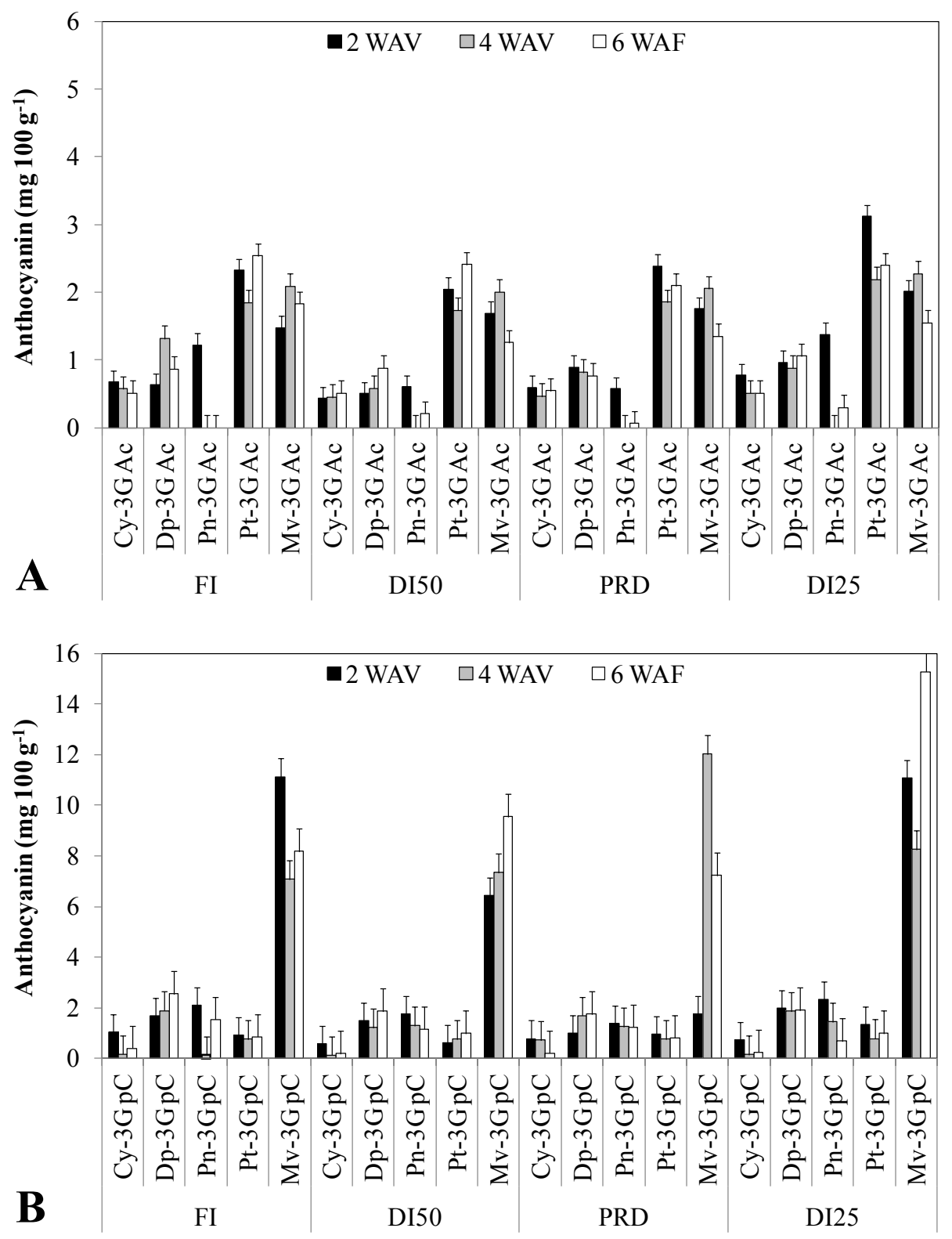

FIGURE 6

Changes in acetyl (A) and coumaroyl-glucoside (B) anthocyanin accumulation in the skin of berries grown under the FI, DI50, $\mathrm{PRD}$ and DI25 treatments. Mean values $\pm \mathrm{SE}(\mathrm{n}=9)$. WAV $=$ weeks after véraison; $\mathrm{Cy}=$ cyanidin; $\mathrm{Dp}=\mathrm{delphinidin} ; \mathrm{Pn}=$ peonidin; $\mathrm{Pt}=$ petunidin; $\mathrm{Mv}=$ malvidin; $3 \mathrm{G}=3$-glucoside; $\mathrm{Ac}=$ acetate; $\mathrm{pC}=\mathrm{p}$-coumarate 


\section{CONCLUSIONS}

In the 2009 growing season, high maximum and mean temperatures, as well as a high number of days with temperatures above $30^{\circ} \mathrm{C}$, were observed in the study area. During berry development, significant differences between treatments were observed as far as light interception was concerned. Higher Rg, PAR, UV and R:FR values were recorded on the southeast side of the canopy in every treatment. As the main leaves started to senesce before harvest in DI25, the southeast cluster zone intercepted significantly higher light intensities, while lower intensities were recorded in both FI and PRD. The lower anthocyanin content of the DI25 berries was likely a consequence of high berry exposure to elevated temperatures, rather than a direct effect of the imposed water stress. The permanence of extreme temperatures in the fruit zone, as well as the phenological time at which they occurred, should be taken into consideration when analysing the effect of cultural practices that affect canopy microclimate on anthocyanin metabolism.

The differences between treatments regarding berry thermal microclimate also seemed to have played a role in anthocyanin metabolism and final composition, namely by favouring partial thermal degradation of the previously accumulated compounds, particularly of malvidin monoglucoside, from mid-ripening. Nevertheless, the higher proportion of the more complex acylated forms found in the DI25 berry skin could be ascribed to both water deficit and better light conditions. Moreover, until four weeks before harvest, PRD induced an increase in acylated forms found in the berry skin, in contrast to the case in DI50. However, the higher total leaf area observed in the PRD plants led to a shadier light microclimate, and this may have caused different anthocyanin metabolism from mid-ripening onward when compared to the two DI treatments.

\section{LITERATURE CITED}

Aeronautica Militare - Servizio Meteorologico, 2009. Atlante climatico d'Italia 1971 - 2000, vol III. Tiferno Grafica s.r.l. Città di Castello (Perugia), 323-338. http://clima.meteoam.it/downloads.php

Allen, R.G., Pereira, L.S., Raes, D. \& Smith, M., 1998. Crop evapotranspiration: Guidelines for computing crop requirements. Irrigation and Drainage Paper No. 56, FAO, Rome, Italy.

ARPAS (Agenzia Regionale per la Protezione dell'Ambiente della Sardegna), 2010. Analisi agrometeorologica e climatologica della Sardegna. Analisi delle condizioni meteorologiche e conseguenze sul territorio regionale nel periodo ottobre 2008 - settembre 2009.

Bergqvist, J., Dokoozlian, N. \& Ebisuda, N., 2001. Sunlight exposure and temperature effects on berry growth and composition of Cabernet Sauvignon and Grenache in the central San Joaquin Valley of California. Am. J. Enol. Vitic. 52, 1-7.

Bindon, K.A., Dry, P.R. \& Loveys, B.R., 2007. Influence of plant water status on the production of C13-norisoprenoid precursors in Vitis vinifera L. cv. Cabernet Sauvignon grape berries. J. Agric. \& Food Chem. 55, 44934500 .

Bindon, K.A., Dry, P.R. \& Loveys, B.R., 2008. Influence of partial rootzone drying (PRD) on the composition and accumulation of anthocyanins in grape berries (Vitis vinifera L. cv. Cabernet Sauvignon). Aust. J. Grape. Wine Res. 14, 91-103.
Bravdo, B.A., Hepner, Y., Loigner, C., Cohen, S. \& Tabacman, H., 1985. Effect of irrigation and crop level on growth, yield, and wine quality of Cabernet Sauvignon. Am. J. Enol. Vitic. 36, 132-139.

Brouwer, C., Prins, K. \& Heibloem, M. 1989. Irrigation water management. Training manual no. 4. Irrigation scheduling. FAO Corporate Document Repository, Natural Resources Management and Environment Department, Rome, Italy.

Castellarin, S.D., Pfeiffer, A., Sivilotti, P., Degan, M., Peterlunger, E. \& Di Gaspero, G., 2007. Transcriptional regulation of anthocyanin biosynthesis in ripening fruit of grapevine under seasonal water deficit. Plant, Cell Env. 30, 1381-1399.

Chapman, D.M., Roby, G., Ebeler, S.E., Guinard, J.X. \& Matthews, M.A., 2005. Sensory attributes of Cabernet Sauvignon wines made from vines with different water status. Aust. J. Grape Wine Res. 11, 339-347.

Chaves, M.M., Zarrouk, O., Francisco, R., Costa, J.M., Santos, T., Regalado, A.P., Rodrigues, M.L. \& Lopes, C.M., 2010. Grapevine under deficit irrigation: Hints from physiological and molecular data. Annals of Botany 105, 661-676.

Cohen, S.D., Tarara, J.M., Gambetta, G.A., Matthews, M.A. \& Kennedy, J.A., 2012. Impact of diurnal temperature variation on grape berry development, proanthocyanidin accumulation, and the expression of flavonoid pathway genes. J. Exp. Bot. 63, 2655-2665.

Cola, G., Mariani, L., Parisi, S. \& Failla, O., 2012. Thermal time and grapevine phenology. Acta Italus Hortus 3, 31-34.

Deluc, L.G., Quilici, D.R., Decendit, A., Grimplet, J., Wheatley, M.D., Schlauch, K.A., Merillon, J.M., Cushman, J.C. \& Cramer, G.R., 2009. Water deficit alters differentially metabolic pathways affecting important flavour and quality traits in grape berries of Cabernet Sauvignon and Chardonnay. BMC Genomics 10, 212.

Di Stefano, R. \& Cravero, M.C., 1991. The grape phenolic determination. Riv. Vitic. Enol., 49, 37-45.

Dokoozlian, N.K. \& Kliewer, W.M., 1996. Influence of light on grape berry growth and composition varies during fruit development. J. Am. Soc. Hort. Sci. 121, 869-874.

Downey, M.O., Dokoozlian, N.K. \& Krstic, M.P., 2006. Cultural practice and environmental impacts on the flavonoid composition of grapes and wine: a review of recent research. Am. J. Enol. Vitic. 57, 257-268.

Downey, M.O., Harvey, J.S. \& Robinson, S.P., 2004. The effect of bunch shading on berry development and flavonoid accumulation in Shiraz grapes. Aust. J. Grape Wine Res. 10, 55-73.

Dry, P.R., 2000. Canopy management for fruitfulness. Aust. J. Grape Wine Res. 6, 109-115.

Fernandes de Oliveira, A., Mameli, M.G., De Pau, L., Satta, D. \& Nieddu, G., 2013. Deficit irrigation strategies in Vitis Vinifera L. cv. Cannonau under Mediterranean climate. Part I - Physiological responses, growth-yield balance and berry composition. S. Afr. J. Enol. Vitic. 34, 170-183.

Gambetta, G.A., Mathews, M.A., Shaghasi, T.H., McElrone, A.J. \& Castellarin, S.D., 2010. Sugar and abscisic acid signalling orthologs are activated at the onset of ripening in grape. Planta 232, 219-234.

Gaudillère, J.P., Van Leeuwen, C. \& Ollat, N., 2002. Carbon isotope composition of sugars in grapevine, an integrated indicator of vineyard water status. J. Exp. Bot. 53, 757-763.

Hardie, W.J. \& Considine, J.A., 1976. Response of grapes to water deficit stress in particular stages of development. Am. J. Enol. Vitic. 27, 55-61.

Haselgrove, L., Botting, D., Van Heeswijck, R., Hoj, P.B., Dry, P.R., Ford, C. \& Iland, P.G., 2000. Canopy microclimate and berry composition: The effect of bunch exposure on the Phenolic composition of Vitis vinifera L. cV Shiraz grape berries. Aust. J. Grape Wine Res. 6, 141-149. 
Kennedy, J.A., Matthews, M.A. \& Waterhouse, A.L., 2002. Effect of maturity and vine water status on grape skin and wine flavonoids. Am. J Enol. Vitic. 53, 268-274.

Mahbrouk, H. \& Sinoquet, H., 1998. Indices of light microclimate and canopy structure determined by 3-D digitising and image analysis and their relationship to grape quality. Aust. J. Grape Wine Res. 4, 2-13.

Matthews, M.A. \& Anderson, M.M., 1989. Reproductive development in grape (Vitis vinifera L.): Responses to seasonal water deficits. Am. J. Enol Vitic. 40, 52-60.

Matthews, M.A., Ishii, R., Anderson, M.M. \& O’Mahony, M., 1990. Dependence of wine sensory attributes on vine water status. J. Sci. Food Agric. 51, 321-335

McCarthy, M., 1997. The effect of transient water deficit on berry development of cv. Shiraz (Vitis vinifera L.). Aust. J. Grape Wine Res. 3, 40-45.

Mori, K., Goto-Yamamoto, N., Masahiko Kitayama, M. \& Hashizume, K., 2007. Loss of anthocyanins in red-wine grape under high temperature. J. Exp. Bot. 58, 1935-1945.

Mori, K., Saito, H., Goto-Yamamoto, N., Kitayama, M., Kobayashi, S., Sugaya, S., Gemma, H. \& Hashizume, K., 2005a. Effects of abscisic acid treatment and night temperatures on anthocyanin composition in 'Pinot noir' grapes. Vitis 44, 161-165.

Mori, K., Sugaya, S. \& Gemma, H., 2005b. Decreased anthocyanin biosynthesis in grape berries grown under elevated night temperature conditions. Sci. Hort. 105, 319-330.

OIV, 1990. Recueil des Methodes Internationales d'Analyses des Vins et Dos Moûts. Office Internationale de la Vigne et du Vin, Paris.

Owen, S.J., Lafond, M.D., Bowen, P., Bogdanoff, C., Usher, K. \& Abrams, S.R., 2009. Profiles of abscisic acid and its catabolites in developing Merlot grape (Vitis vinifera) berries. Am. J. Enol. Vitic. 60, 277-284.

Roby, G. \& Matthews, M.A., 2004. Relative proportions of seed, skin and flesh, in ripe berries from Cabernet Sauvignon grapevines grown in a vineyard either well irrigated or under water deficit. Aust. J. Grape Wine Res. 10, 74-82.

Roby, G., Harbertson, J.F., Adams, D.A. \& Matthews, M.A., 2004. Berry size and vine water deficits as factors in winegrape composition: Anthocyanins and tannins. Aust. J. Grape Wine Res. 10, 100-107.

Rodriguez-Sanoa, L.E., Giusti, M.M. \& Wrolstad, R.E., 1999. Color and pigment stability of red radish and red-fleshed potato anthocyanins in juice model systems. J. Food Sci. 64,451-456.
Romero, P., Fernandez-Fernandez, J.I. \& Martinez-Cutillas, A., 2010. Physiological thresholds for efficient regulated deficit irrigation management in winegrapes grown under semiarid conditions. Am. J. Enol. Vitic. 61, 300-312.

Rustioni, L., Rossoni, M., Cola, G., Mariani, L. \& Failla, O., 2006. Microclima termico e luminoso e accumulo di antociani in 'Nebbiolo'. Quad. Vitic. Enol. Univ. Torino 28, 137-147.

Santos, T.P., Lopes, C.M., Rodrigues, M.L., Souza, C.R., Ricardo-da-Silva, J.M., Maroco, J.P., Pereira, J.S. \& Chaves, M.M., 2007. Effect of deficit irrigation strategies on cluster microclimate for improving fruit composition of Moscatel field-grown grapevines. Sci. Hort. 112, 321-330.

Schultz, H.R., 1996. Water relations and photosynthetic responses of two grapevine cultivars of different geographical origin during water stress. Acta Hort. 427, 251-266.

Schultz, H.R., 2000. Climate changes and viticulture: A European perspective on climatology, carbon dioxide and UV B effects. Aust. J. Grape Wine Res. 6, 2-12.

Spayd, S.E., Tarara, J.M., Mee, D.L. \& Ferguson, J.C., 2002. Separation of sunlight and temperature effects on the composition of Vitis vinifera cv. Merlot berries. Am. J. Enol. Vitic. 53, 171-182.

Tarara, J.M., Lee, J., Spayd, S.E. \& Scagel, C.F., 2008. Berry temperature and solar radiation alter acylation proportion, and concentration of anthocyanin in Merlot grapes. Am. J. Enol. Vitic. 59, 235-247.

Van Zyl, J.L., 1984. Response of Colombar grapevines to irrigation as regards quality aspects and growth. S. Afr. J. Enol. Vitic. 5, 19-28.

Williams, L.E. \& Arays, J.E., 2005. Grapevine water use and the crop coefficient are linear functions of the shaded area measured beneath the canopy. Agric. Forest Meteor. 132, 201-211.

Williams, L.E. \& Matthews, M.A., 1990. Grapevine. In: Stewart B.A. \& Nielsen D.R. (eds). Irrigation of agricultural crops. Series of Agronomy. vol 30. American Society of Agronomy, Madison, Wisconsin, USA, $1019-1055$.

Yamane, T., Jeong, S.T., Goto-Yamamoto, N., Koshita, Y. \& Kobayashi, S., 2006. Effects of temperature on anthocyanin biosynthesis in grape berry skins. Am. J. Enol. Vitic. 57, 54-59.

Yan, W. \& Hunt, L.A., 1999. An equation for modeling the temperature response of plants using only the cardinal temperatures. Ann. Bot. 84, 607614 . 